\title{
Cladosporium fulvum Avr4 Protects Fungal Cell Walls Against Hydrolysis by Plant Chitinases Accumulating During Infection
}

\author{
Harrold A. van den Burg, ${ }^{1,2}$ Stuart J. Harrison, ${ }^{3}$ Matthieu H. A. J. Joosten, ${ }^{2}$ Jacques Vervoort, ${ }^{1}$ and \\ Pierre J. G. M. de Wit ${ }^{2}$ \\ ${ }^{1}$ Laboratory of Biochemistry, Wageningen University, Dreijenlaan 3, NL-6703 HA Wageningen, The Netherlands; \\ ${ }^{2}$ Laboratory of Phytopathology, Wageningen University, Binnenhaven 5, NL-6709 PD Wageningen, The Netherlands; \\ ${ }^{3}$ Syngenta-Mogen, Einsteinweg 97, 2333 CB Leiden, Netherlands, Syngenta Mogen, Einsteinweg 97, 2333 CB Leiden, The \\ Netherlands
}

Submitted 31 May 2006. Accepted 12 July 2006.

\begin{abstract}
Resistance against the leaf mold fungus Cladosporium fulvum is mediated by the tomato Cf proteins which belong to the class of receptor-like proteins and indirectly recognize extracellular avirulence proteins (Avrs) of the fungus. Apart from triggering disease resistance, Avrs are believed to play a role in pathogenicity or virulence of $C$. fulvum. Here, we report on the avirulence protein Avr4, which is a chitin-binding lectin containing an invertebrate chitin-binding domain (CBM14). This domain is found in many eukaryotes, but has not yet been described in fungal or plant genomes. We found that interaction of Avr4 with chitin is specific, because it does not interact with other cell wall polysaccharides. Avr4 binds to chitin oligomers with a minimal length of three $\mathrm{N}$-acetyl glucosamine residues. In vitro, Avr4 protects chitin against hydrolysis by plant chitinases. Avr4 also binds to chitin in cell walls of the fungi Trichoderma viride and Fusarium solani f. sp. phaseoli and protects these fungi against normally deleterious concentrations of plant chitinases. In situ fluorescence studies showed that Avr4 also binds to cell walls of $C$. fulvum during infection of tomato, where it most likely protects the fungus against tomato chitinases, suggesting that Avr4 is a counter-defensive virulence factor.
\end{abstract}

Additional keywords: defense, hypersensitive response, resistance genes.

Plants have evolved sophisticated active defense mechanisms against potential pathogens. These mechanisms include a hypersensitive response (HR), consisting of localized cell death at the site of infection, enforcements of plant cell walls, release of reactive oxygen species, and de novo production of antim-

Corresponding author: P. J. G. M de Wit; Telephone: +31 317 483130; Fax:+31317483412; E-mail: pierre.dewit@wur.nl

Current address of H. A. van den Burg: Department of Plant Pathology, Swammerdam Institute of Life Sciences, Universiteit van Amsterdam, Kruislaan 318, 1098 SM Amsterdam, The Netherlands.

Current address of S. J. Harrison: Syngenta, Jealott's Hill International Research Centre, Bracknell, Berkshire RG42 6EY, U. K.

* The $\boldsymbol{e}$-Xtra logo stands for "electronic extra" and indicates the HTML abstract available on-line contains supplemental material not included in the print edition. There are three supplemental figures published online. icrobial compounds such as pathogenesis-related (PR) proteins, phytoalexins, and other secondary metabolites (Darvill and Albersheim 1984; Datta and Muthukrishnan 1999; Sudha and Ravishankar 2002; Tudzynski and Sharon 2003). PR proteins accumulate in large amounts in vacuoles and the apoplast, where they inhibit growth of penetrating fungal pathogens (Benhamou et al. 1990; Datta and Muthukrishnan 1999; Daugrois et al. 1990; Hu and Rijkenberg 1998; Kang and Buchenauer 2002; Stintzi et al. 1993). PR proteins include different classes of proteins that can hydrolyze various components of fungal cells walls (glucans, chitin, and proteins), such as fungal cell-wall-degrading enzymes (e.g., $\beta$-1,3-glucanases [PR-2] and chitinases [PR-3/8/11]) and serine and cysteine proteases (e.g., P69 and Rcr3), respectively (Datta and Muthukrishnan 1999; Jorda et al. 1999; Jorda and Vera 2000; Krüger et al. 2002).

These host defense responses are triggered when plants recognize pathogen-derived molecules (also called elicitors or avirulence factors). Successful plant pathogens cope with these defense responses by either avoiding recognition by the plant or neutralizing host defense responses (Bishop et al. 2005; Ham et al. 1997; Rooney et al. 2005; Rose et al. 2002; Tian et al. 2004, 2005; Tian et al. 2005; Tian and Kamoun 2005; York et al. 2004). A well-characterized example of avoiding recognition occurs in an incompatible interaction between tomato and the pathogenic fungus Cladosporium fulvum (synonym: Passalora fulva) (Rivas and Thomas 2005; Thomma et al. 2005). Tomato $C f$ resistance gene products mediate recognition of fungal avirulence gene $(A v r)$ products in a gene-forgene-dependent manner. Upon recognition, $\mathrm{Cf}$ proteins activate the full signaling cascade leading to the described defense responses, including HR (De Wit et al. 2002; Joosten and De Wit 1999). Virulent isolates of C. fulvum are not recognized because they lack a particular Avr gene (van Kan et al. 1991) or carry polymorphic alleles of Avr genes with point mutations, deletions, or transposon insertions in the coding sequence (Joosten and De Wit 1999; Thomma et al. 2005). These mutations prevent recognition by the matching receptor-like Cf proteins (Joosten et al. 1994, 1997; Luderer et al. 2002; Westerink et al. 2004). In addition, five extracellular proteins (Ecps) have been isolated form the apoplast of C. fulvum-infected plants. These Ecps also are recognized by some wild tomato accessions, as is manifested by an HR (Laugé et al. 1997, 2000; Marmeisse et al. 1994). In contrast to the Avr genes, allelic variation has not yet been found for Ecp genes, which could be 
due to the fact that Ecp-recognizing resistance genes (Cf-Ecps) have not yet been introduced in commercial tomato cultivars (De Kock et al. 2004a,b; Laugé et al. 2000). An intrinsic function recently was reported for the Avr2 protein of C. fulvum because it appears to be an inhibitor of the tomato cysteine protease Rcr3 (Rooney et al. 2005) and can be considered a counter-defensive virulence factor. In the presence of the tomato Cf-2 protein, Avr2 functions as an avirulence factor, because binding to and inhibition of Rcr3 by Avr2 is sensed by Cf-2 followed by triggering an HR. The intrinsic functions of Avr4, Avr4E, and Avr9 have not yet been identified; however, it has been hypothesized that they also might neutralize or suppress tomato defense proteins, as expected from their size, localization, and expression patterns (i.e., these proteins are 3 to $8 \mathrm{kDa}$ in size, nonenzymatic, cysteine-rich, stable extracellular proteins produced during infection) (De Wit et al. 2002; Joosten and De Wit 1999). Avr9 was shown to have structural homology to a carboxypeptidase inhibitor; however, inhibition of carboxypeptidase activity could not be proven experimentally, suggesting that the homology is structural rather than functional (Van den Hooven et al. 2001; Vervoort et al. 1997). Avr4 was shown to contain an invertebrate chitin-binding domain (also denoted CBM14 in the CAZY classification) (van den Burg et al. 2003, 2004). Chitin is a major structural component of the fungal cell wall and is a target of plant chitinases as part of the host defense response (Grison et al. 1996; Mauch et al. 1988; Schlumbaum et al. 1986; Sela-Buurlage et al. 1993; Stintzi et al. 1993; Zhu et al. 1994), which also has been suggested for the C. fulvum-tomato interaction (Wubben et al. 1993).

Here, we provide evidence for dual roles of Avr4 of C. fulvum during infection of tomato. Initially, Avr4 was identified as an extracellular race-specific elicitor (avirulence factor) that induces HR in tomato plants carrying the matching $C f-4$ resistance gene (Joosten et al. 1994; Thomas et al. 1997). In this article, we suggest a role of Avr4 in virulence for C. fulvum by providing protection of its cell walls against plant chitinases by its binding to chitin. Most isolates of $C$. fulvum that evade $C f$-4-mediated resistance secrete protease-sensitive isoforms of Avr4 (Joosten et al. 1997; van den Burg et al. 2003). The corresponding virulent avr4 alleles contain single nucleotide polymorphisms that, in most cases, result in Cys-to-Tyr substitutions in the encoded proteins. These substitutions destroy a disulfide bond and thereby affect stability of the Avr4 isoforms and cause their degradation in the harsh, protease-rich environ- ment of the apoplast (Joosten et al. 1997; van den Burg et al. 2003; Van Esse et al. 2006). The three disulfide bonds that stabilize the protein fold form a disulfide bond pattern identical to the pattern found in CBM14 (Kawabata et al. 1996; Shen and Jacobs-Lorena 1999; Suetake et al. 2000; van den Burg et al. 2003). Structural studies confirmed that the protein fold of Avr4 is similar to that of tachycitin, a well-studied member of proteins with the CBM14 domain (van den Burg et al. 2004). Disruption of the additional fourth disulfide bond did not cause degradation of Avr4 by proteases present in the tomato apoplast (van den Burg et al. 2003). Avr4 binds specifically to fungal cell wall preparations but not to tomato cell wall preparations (Westerink et al. 2002; this article). Here, we show that Avr4 binds specifically to chitin and not to other cell wall polysaccharides. Avr4 reduces chitin hydrolysis in vitro and protects the fungi Trichoderma viride and Fusarium solani f. sp. phaseoli against the deleterious effects of mixtures of plant chitinases and $\beta$-1,3-glucanases. In situ microscopic analysis confirmed that Avr4 not only binds to cell walls of the latter two fungi but also to those of $C$. fulvum itself during infection.

\section{RESULTS}

\section{Avr4 binds specifically to chitin.}

We previously reported that Avr4 can interact with three $\mathrm{N}$ acetyl glucosamine (GlcNAc) residues. Hence, the chitin-binding site of Avr4 is fully occupied when chitotriose is bound to Avr4 (van den Burg et al. 2004). In the same experiments, we found that Avr4 does not show any affinity for smaller soluble chitin fragments like the dimer chitobiose (GlcNAc) $)_{2}$ or the monomer N-acetyl glucosamine (GlcNAc). Here, we examined whether Avr4 has affinity for insoluble polysaccharides other than chitin using an affinity precipitation assay. The tested polysaccharides included cell wall components of various organisms. In addition to Avr4, we used three other proteins as controls in the affinity precipitation assay, including i) the well-characterized plant chitin-binding lectin wheat germ agglutinin (WGA) as a positive control for chitin-binding (Bains et al. 1992), and the extracellular proteins ii) Ecp1 (Van den Ackerveken et al. 1993) and iii) Ecp4 of C. fulvum (Laugé et al. 2000) as negative controls. WGA could be affinity precipitated readily with both chitin and chitosan (Fig. 1A), whereas Ecp1 and Ecp4 remained in solution with all tested polysaccharides (Fig. 1A). Avr4 was readily affinity precipitated in the presence of chitin (by both

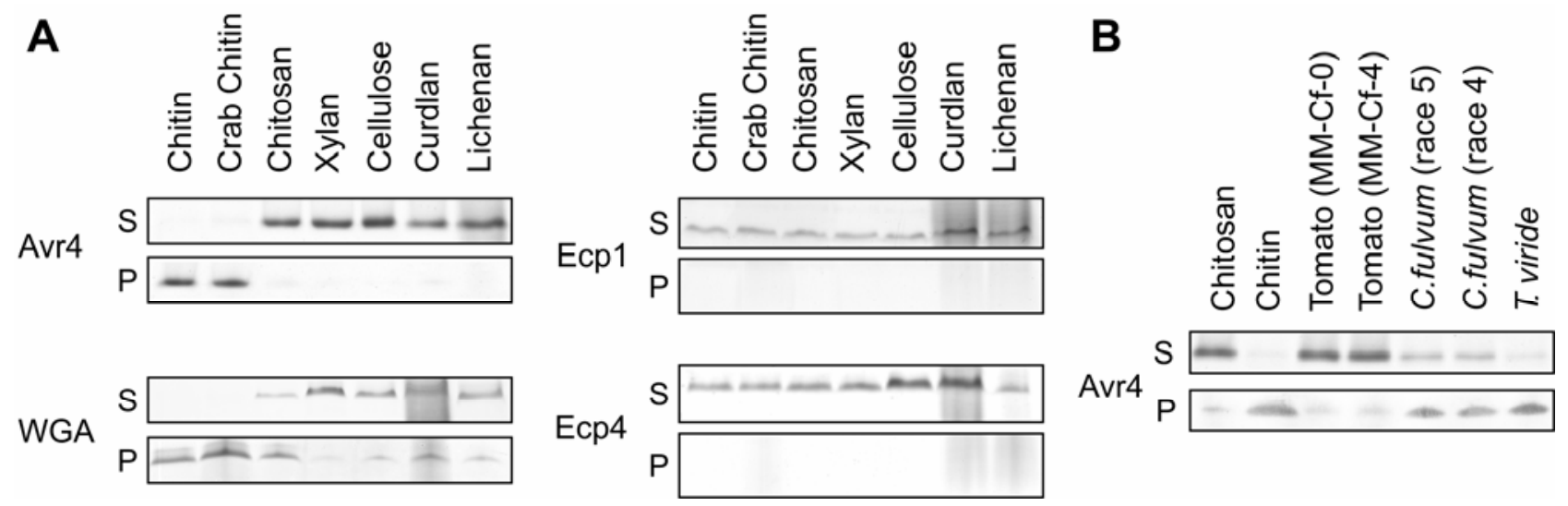

Fig. 1. Affinity precipitation of avirulence protein (Avr)4, wheat germ agglutinin (WGA), extracellular protein (Ecp)1, and Ecp4 with A, insoluble polysaccharides and B, polysaccharide-enriched cell wall extracts of plants and fungi. A, Avr4 is specifically precipitated with chitin (beads) and chitin from crab shells, whereas WGA binds to both chitin sources and to chitosan. Ecp1 and Ecp4 are included as negative controls for polysaccharide binding. S, protein remaining in the concentrated supernatant fraction; $\mathrm{P}$, protein bound to insoluble polysaccharide fraction. B, Avr4 affinity precipitation with cell walls obtained from tomato (i.e., MM-Cf-0 and MM-Cf-4) and the fungi Cladosporium fulvum and Trichoderma viride. C. fulvum extracts were prepared from an Avr4-producing strain (race 5) and an Avr4 nonproducing strain (race 4). Chitin and chitosan are included as positive and negative binding controls, respectively. Note that Avr4 associates only with insoluble chitin or chitin-containing fungal cell walls. 
chitin beads and crab shell chitin), but not with any of the other polysaccharides, including curdlan (a 1,3- $\beta$-D glucan from bacteria), lichenan (a 1,3 to 1,4- $\beta$-D glucan from lichens), and chitosan (Fig. 1A). Boiling of the Avr4-containing chitin pellet in 1\% sodium dodecyl sulfate (SDS) caused dissociation of Avr4 from chitin. Binding of Avr4 to chitin also was found to be (partially) reversible under acidic conditions. This is in agreement with the observation that allosteric interactions between Avr4 and chitin were negatively affected by acidic $\mathrm{pH}$ (acidic conditions decreased the number of Avr4 molecules from two to one Avr4 molecule that bind to a single [GlcNAc] ${ }_{6}$ chain) (van den Burg et al. 2004). Overall, we conclude that Avr4 binds specifically to chitin but not to other common fungal or plant cell wall polysaccharides.

During infection, $C$. fulvum remains confined to the apoplast of tomato leaves (De Wit 1977), where Avr4 is secreted and exposed to both fungal and plant cell wall components. Avr4 is not expected to bind to tomato cell walls because these do not contain chitin. To experimentally prove this, we prepared cell wall preparations from fungal and tomato cell walls by a method that enriches for polysaccharides. These extracts subsequently were used for Avr4 affinity-precipitation assays where chitin and chitosan were included as controls. Avr4 could not be precipitated by the tomato cell walls, whereas Avr4 was readily precipitated by fungal cell walls obtained from C. fulvum (Fig. 1B). Cell walls also were prepared from the soilborne fungus $T$. viride, because it has been reported that its cell wall is readily accessible to chitinases (Mauch et al. 1988). We noticed consistently that slightly increased levels of Avr4 were precipitated with the $T$. viride cell wall extracts compared with the $C$. fulvum cell wall extracts. This may reflect a difference in chitin content or chitin accessibility between the two types of fungal cell walls. Overall, this experiment confirms that Avr4 binds to a component that is present in fungal cell walls but absent in plant cell walls. The best candidate is chitin because it has a high affinity for Avr4 and is abundantly present in fungal cell walls but absent in plant cell walls (Wessels and Sietsma 1981).

\section{Binding of Avr4}

to chitin prevents chitin hydrolysis by chitinases.

Large amounts of chitinases are secreted in vacuoles and apoplast as part of the plant defense response to inhibit growth of pathogenic fungi. Successful plant-pathogenic fungi are be- lieved to have evolved a mechanism to directly or indirectly counteract chitinase activity. This prompted us to test whether Avr4 could play such a role. We used the well-characterized basic chitinase (Chil) of tobacco (Sela-Buurlage et al. 1993) with insoluble chitin azure as chitinase substrate. Using the affinity precipitation assay, we confirmed that Avr4 specifically binds to chitin azure similarly as to chitin (Fig. 2A). To ensure complete binding of Avr4 to chitin azure, Avr4 was saturated with chitin azure prior to adding ChiI. In the presence of increased Avr4 concentrations, we observed that the chitinase activity of ChiI was reduced, whereas similar concentrations of Ecp1 had no effect on chitinase activity (Fig. 2B). Preincubation of Avr4 with a threefold molar excess of the hexamer (GlcNAc) $)_{6}$ relative to Avr4 titrated out Avr4 and restored chitinase activity to control levels (Fig. 2B). Brunner and associates (1998) previously had shown that chito-oligomers consisting of four or more GlcNAc residues are rapidly degraded by all types of plant chitinases, leading to short half-lives of chitooligomers in the presence of chitinases. The experimental setup does not detect hydrolysis of unlabeled (GlcNAc) ${ }_{6}$, but detects only the release of azure-conjugated chito-oligomers. The recovery of the chitinase activity in the presence of chitin azure implies, therefore, that the majority of Avr4 remained bound to $(\text { GlcNAc) })_{6}$ under these conditions. For that reason, Avr4 must have a higher apparent affinity for $(\mathrm{GlcNAc})_{6}$ than for chitin azure. In addition, the experiment demonstrates that Avr4 does not inhibit chitinase activity directly but, rather, indirectly by interfering with substrate accessibility.

\section{Avr4 protects fungi \\ against the deleterious effects of plant chitinases.}

Subsequently, we examined whether Avr4 can protect fungi in vitro against the deleterious effects of plant chitinases. We used the fungi $T$. viride and $F$. solani $\mathrm{f}$. sp. phaseoli for this assay, because they have been reported to be highly sensitive to combinations of plant chitinases and $\beta$-1,3-glucanases. Growth of $T$. viride is inhibited by ChiI alone (Mauch et al. 1988), whereas a mixture of both ChiI and $\beta$-1,3-glucanases (GluI) is needed to inhibit growth of $F$. solani f. sp. phaseoli (Sela-Buurlage et al. 1993). In the presence of $0.3 \mu \mathrm{M}$ ChiI, almost all $T$. viride germlings were lysed within 24 h (Fig. 3A). However, when Avr4 was added prior to the addition of chitinase, growth of $T$. viride germlings was protected against ChiI in an Avr4-dependent manner (Fig. 3B and E). The protection of T. viride against ChiI

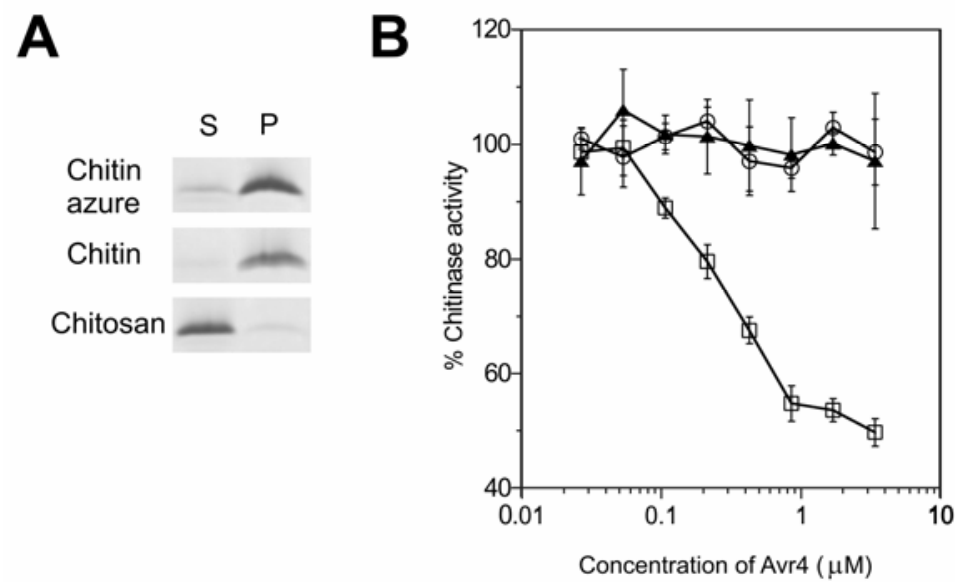

Fig. 2. Decrease of hydrolytic activity of tobacco basic chitinase (ChiI) in the presence of avirulence protein (Avr)4. A, Affinity precipitation of Avr4 with chemically modified chitin azure that was used as a chitin substrate. Chitin and chitosan were included as positive and negative controls, respectively. S, concentrated supernatant; P, pellet with insoluble polysaccharide fraction. B, Hydrolytic activity of ChiI in the presence of Avr4 ( $\square$ ), extracellular protein (Ecp)1 (O), and Avr4 pre-incubated with a threefold molar excess of (GlcNAc) 6 ( $\mathbf{\Delta})$. Enzymatic activity was quantified as an increase of absorbance at 550 $\mathrm{nm}$ (caused by release of azure-conjugated chito-oligomers). Error bars indicate \pm standard error between three independent replicate experiments. 
was specific for Avr4, because similar or higher concentrations of Ecp1 did not protect $T$. viride germlings (data not shown). The growth of $T$. viride germlings was not affected by adding Avr4 only (data not shown). Similarly, we observed that Avr4 protected $F$. solani $\mathrm{f}$. sp. phaseoli germlings. In the presence of both $0.3 \mu \mathrm{M}$ ChiI and $0.3 \mu \mathrm{M}$ GluI, growth of the $F$. solani $\mathrm{f}$. sp. phaseoli germlings was almost completely inhibited (Fig. 3C); whereas, after pretreatment with increasing concentrations of Avr4, the germlings could be fully protected (Fig. 3D end E). Similar concentrations of Ecp1 could not protect $F$. solani $\mathrm{f}$. sp. phaseoli in the presence of ChiI and GluI. The growth of $F$. solani f. sp. phaseoli germlings was not affected by adding Avr4 only (data not shown). Overall, we achieved $50 \%$ protection of T. viride and F. solani f. sp. phaseoli at a concentration of Avr4 of 4 and $1 \mu \mathrm{M}$, respectively (Fig. 3E).

\section{Avr4 binds to chitin present}

in cell walls of $T$. viride and $\boldsymbol{F}$. solani f. sp. phaseoli.

The previous findings suggest that Avr4 protects T. viride and $F$. solani f. sp. phaseoli against plant chitinases by binding to chitin present in their cell walls. This hypothesis was examined further by performing in situ localization studies using fluorescently labeled Avr4. For these studies, the fluorescent dye BODIPY-TMR-SE (BDP) was conjugated to Avr4 and we confirmed that the dye-conjugated from Avr4-BDP was still biologically active by confirming that Avr4-BDP still specifically binds to chitin and that Avr4-BDP still induces a $C f-4$ dependent $\mathrm{HR}$ in tomato. We also confirmed that the BDP moiety does not unspecifically bind to polysaccharides by conjugating BDP to Avr2, and proved subsequently that Avr2-BDP does not specifically bind to chitin or any other polysaccharide (data not shown). Finally, we used WGA conjugated to the fluorescent dye Oregon green (WGA-OG) as a positive control for the in situ chitin localization studies (Benhamou et al. 1990). We also established that WGA-OG binds specifically to chitin and chitosan similarly to unconjugated WGA using the affinity precipitation assay (Fig. 1A).

Subsequently, we incubated germlings of $T$. viride and $F$. solani f. sp. phaseoli with both WGA-OG and Avr4-BDP. In the case of T. viride, WGA-OG and Avr4-BDP accumulated at the surface of both the germ tubes and swollen conidia without any noticeable difference between both dye-conjugated proteins

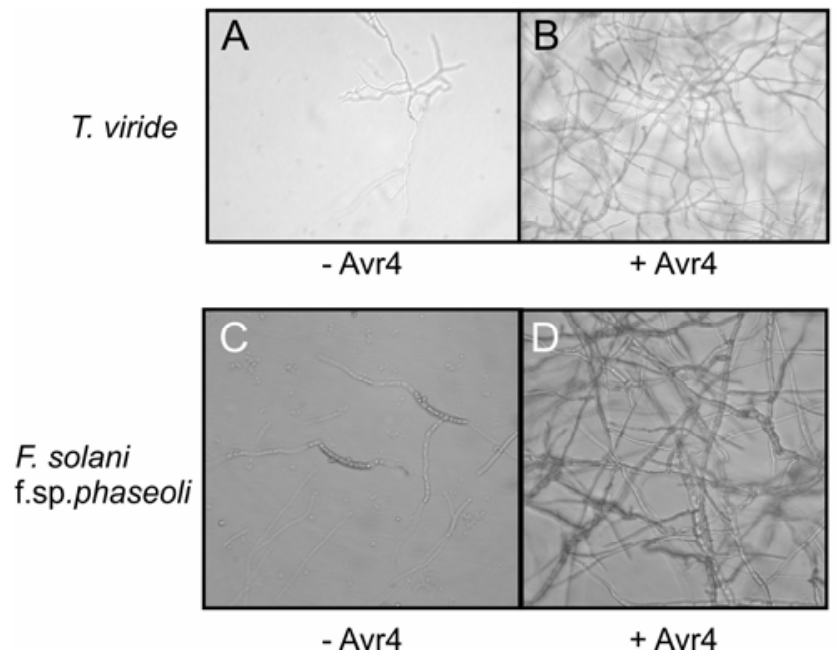

(Fig. 4A to D). The cell wall labeling is the result of binding of dye-labeled protein to chitin present in the cell wall, because pretreatments of $T$. viride germlings with chitinases prevented cell wall labeling with both WGA-OG and Avr4-BDP and caused substantial lysis (results not shown).

A slightly different picture was observed for $F$. solani $\mathrm{f}$. sp. phaseoli (Fig. 4E to $\mathrm{G}$ ). Both dye-labeled proteins accumulated at germ tubes and conidia of $F$. solani f. sp. phaseoli; however, the conidia were stained only at the protrusion of the germ tube where the cell wall is actively dissolved and resynthesized. Moreover, the fluorescent signal was not equally distributed over the entire germ tube, which is in contrast to what was observed for $T$. viride. It suggests that the chitin layer in the cell wall of $F$. solani f. sp. phaseoli is partly covered by other cell wall components. Nongerminated conidia of both fungi were not stained by either dye (Fig. 4C, D, and G). In conclusion, the in situ localization studies indicated that binding of Avr4 to chitin likely explains the protection of the tested fungi against chitindegrading enzymes.

\section{Avr4 does not bind \\ to mycelium of in vitro-grown $C$. fulvum.}

Previously, Joosten and associates (1995), with similar in vitro experiments, showed that growth of $C$. fulvum is not inhibited by high concentrations of tomato chitinases and $\beta-1,3$-glucanases and that these enzymes do not cause hyphal lysis. In addition, electron microscopic studies had shown that the cell wall of infectious $C$. fulvum hyphae highly resembles that of other filamentous ascomycetes (i.e., chitin is present in the inner cell wall layers and is covered by an electron-dense outer layer) (Wubben 1994). Here, we tested whether Avr4-BDP can bind to cell walls of in vitro-germinated $C$. fulvum conidia. Initially, we observed only faint staining of the septa when fully germinated C. fulvum conidia were incubated with WGA-OG or Avr4-BDP (data not shown). These observations were independent of the $C$. fulvum strain used (including a non-Avr4-producing race 4 or an Avr4-producing race 5). This could indicate that the mature hyphal cell wall of $C$. fulvum does not allow free diffusion of WGA-OG or Avr4-BDP to chitin present in the inner cell wall layers. For several ascomycetes, it has been documented that the electron-dense outer layer is largely composed of cell-wallanchored proteins that limit free diffusion of proteins through
$E$

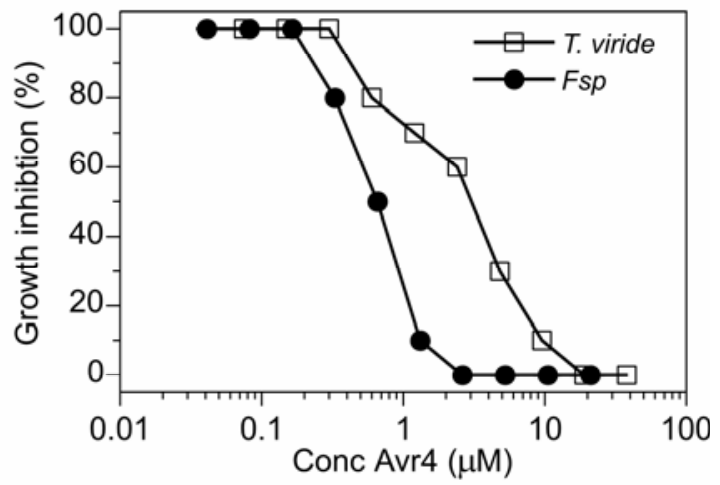

Fig. 3. Growth inhibition of the fungi Trichoderma viride and Fusarium solani f. sp. phaseoli (Fsp) when treated with basic chitinase (ChiI) and $\beta$-1,3glucanase (GluI) in the presence of avirulence protein (Avr)4. A, Germinated conidia of T. viride incubated with $0.3 \mu \mathrm{M}$ ChiI for 24 h. B, Similar as in A, except that the germinated conidia were pre-incubated with $38 \mu \mathrm{M}$ Avr4. C, Germinated conidia of Fsp incubated with $0.3 \mu \mathrm{M}$ ChiI and $0.3 \mu \mathrm{M}$ GluI for 24 h. D, Similar as in C, except that the germinating conidia were pre-incubated with $6 \mu \mathrm{M}$ Avr4. E, Determination of effective dose of Avr4 that gives $50 \%$ growth restoration for T. viride $(\square)$ and Fsp $(\bigcirc)$ when treated with ChiI and GluI. Enzyme treatments were identical as described for A-D. Data shown are the result of a typical experiment with at least three independent replicates with comparable results. 
the cell wall matrix (de Groot et al. 2005). It also could indicate that chitin is blocked by other lectins or unknown cell wall modifications. To distinguish between these two possibilities, we added WGA-OG or Avr4-BDP directly to germinating conidia. This resulted in accumulation of both dye-labeled proteins at the site of protrusion of the germ tube from the conidium (Fig. 5A and B). Thus, Avr4 can bind to chitin in the newly formed cell walls at the protruding germ tube, but it also indicates that chitin is rapidly shielded during de novo cell wall synthesis. Subsequently, we examined whether a treatment with Zymolase, which is a mixture of proteases and glucanases, could increase binding of WGA-OG or Avr-BDP to the germ tubes of $C$. fulvum. The Zymolase treatment resulted in full staining of the germ tubes with both WGA-OG and Avr4-BDP (Fig. 5C and D). Furthermore, preincubation of Zymolase with a protease inhibitor cocktail prevented Avr4-BDP localization at the hyphal surface of $C$. fulvum and treatment with Pronase alone did not result in Avr4-BDP localization at the hyphal surface (data not shown). These data indicate that cell-wall-incorporated proteins together with the glucan matrix contribute to the restricted accessibility of chitin under in vitro growth conditions.

\section{Avr4 is accessible to chitin in infectious hyphae} of $C$. fulvum during colonization of tomato leaves.

Following our in vitro experiments, we performed labeling studies on tomato leaves inoculated with virulent and avirulent C. fulvum strains. Fully expanded leaves of 6-week-old tomato plants of cv. Moneymaker (MM-Cf-0, MM-Cf-4, and MM-Cf$5)$ were inoculated with either race 4 or race 5 of $C$. fulvum and leaf samples were taken at 5 and 9 days post inoculation (dpi). These two time points represent two clearly distinct stages of the $C$. fulvum infection, representing abaxial growth on the leaf surface and early penetration (5 dpi) versus full colonization of the tomato apoplast of susceptible plants by virulent races $(9 \mathrm{dpi})$. Epidermal peelings were prepared from the abaxial side of inoculated leaves at $5 \mathrm{dpi}$ and incubated with Avr4-BDP or WGA-OG. After extensive washing, the samples were examined with confocal laser-scanning microscopy (CLSM). Both WGA-OG (result not shown) and Avr4BDP labeled the entire surface of the runner hyphae present on the abaxial surface of expanded tomato leaves (Fig. 6A). This indicates that chitin in cell walls of runner hyphae is highly accessible for Avr4. We also noted low levels of staining at the epidermal cell walls; however, this was considered nonspecific because similar levels of staining were achieved with the negative control Avr2-BDP (results not shown). The intense labeling of the surface of the runner hyphae with Avr4-BDP strongly contrasts with the lack of signal observed at the surface of in vitro-grown C. fulvum mycelium. At $5 \mathrm{dpi}$, we observed no differences in staining intensity between the two strains of $C$. fulvum that we tested, which is not surprising because growth of virulent and avirulent strains on susceptible and resistant cultivars is not significantly different at this stage of infection.
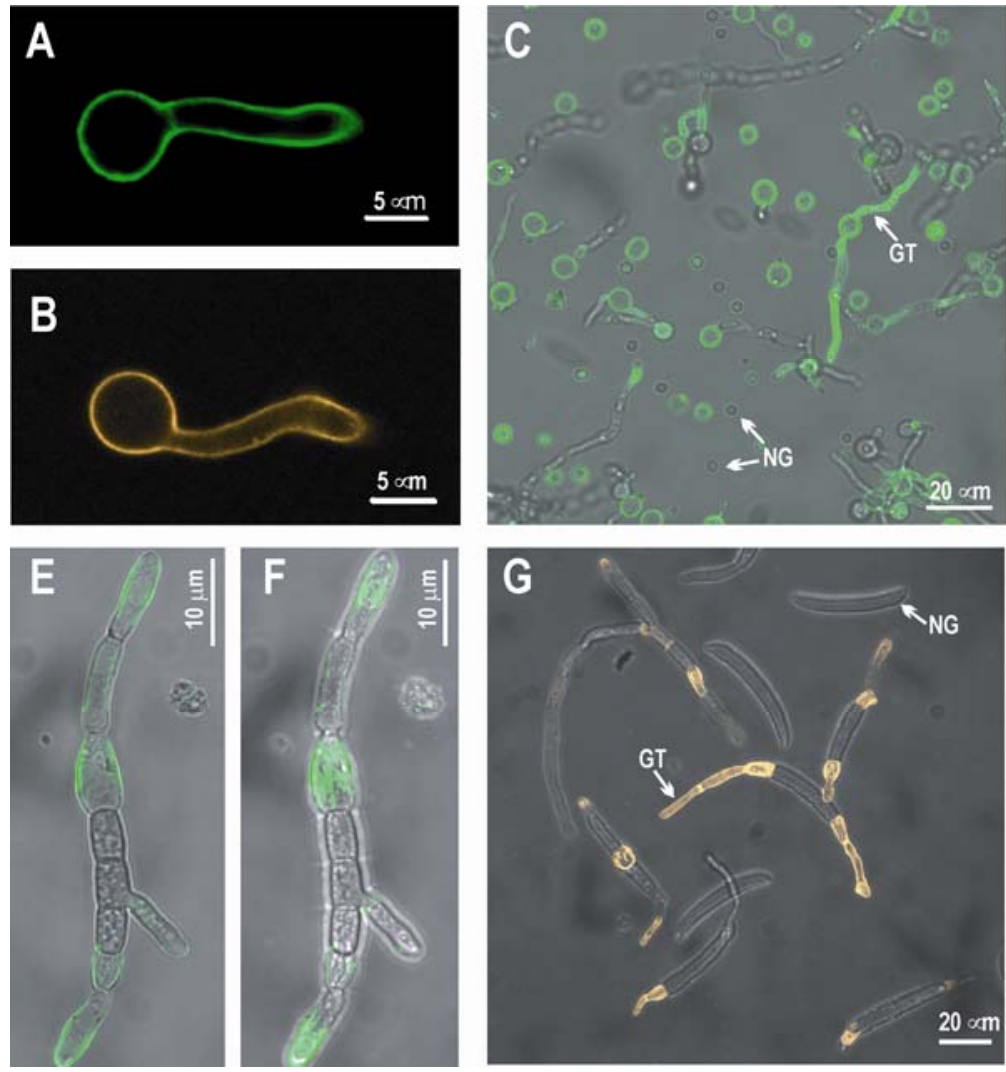

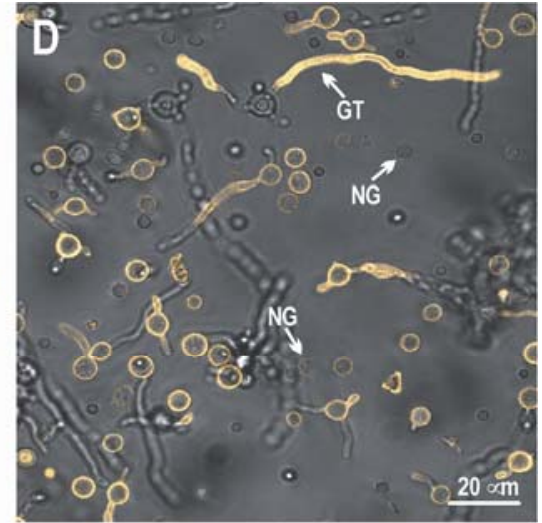

Fig. 4. In situ localization of fluorescently labeled avirulence protein (Avr)4 and wheat germ agglutinin (WGA) on germinating conidia of A to D, Trichoderma viride and E-G, Fusarium solani f. sp. phaseoli. A and C, Oregon green-conjugated WGA (WGA-OG; green color) localizes at the surface of swollen conidia and protruding hyphae $(\rightarrow \mathrm{GT})$ of $T$. viride, but not at the surface of nongerminated conidia $(\rightarrow \mathrm{NG})$. B and D, similar to A and C, respectively, except that the germinated conidia were incubated with BODIPY-TMR-SE (BDP)-conjugated Avr4 (Avr4-BDP; yellow color). Localization of Avr4 is very similar to that of WGA-OG (A and $\mathbf{B}$ are fluorescent images only, whereas $\mathbf{C}$ and $\mathbf{D}$ are overlays of the bright field and confocal image). $\mathbf{E}$ and $\mathbf{F}$, WGA-OG staining of a germinated conidium of $F$. solani $\mathrm{f}$. sp. phaseoli, where $\mathbf{E}$ shows an overlay of bright field and a single confocal image taken at half height through the conidium, demonstrating surface labeling with WGA-OG. F, Combined image of several confocal z-stacks of the same germling as in $\mathbf{E}$ showing unequal surface labeling at the germ tube protruding from the $F$. solani $\mathrm{f}$. sp. phaseoli conidium. G, Avr4-BDP labeling of germinating conidia of $F$. solani $\mathrm{f}$. sp. phaseoli. Again, Avr4-BDP localization is similar to that of WGA-OG on the surface of $F$. solani f. sp. phaseoli conidia and the protruding germ tube. For all observations, conidia were germinated overnight and subsequently incubated with dye-conjugated protein for 2 to $3 \mathrm{~h}$ prior to analysis. 
At 9 dpi, the apoplast of susceptible tomato leaves was fully colonized by intercellular infectious hyphae that had formed an extensive network of mycelium. The binding of Avr4 to infectious hyphae also was analyzed by vacuum infiltration of the apoplast with Avr4-BDP or WGA-OG (incubation for at least $1 \mathrm{~h}$ ). This procedure enabled us to label both the runner hyphae on the epidermal surface and intercellular hyphae in the tomato apoplast in a nondestructive manner. Subsequently, epidermal peelings (that contained a substantial number of intercellular hyphae) were prepared, washed, and examined by CLSM. With this method, we observed again that Avr4-BDP labeled the surface of the runner hyphae at 9 dpi (Fig. 6B). In addition, we noted labeling of the surface of intercellular hyphae growing in the tomato apoplast (Fig. 6C). Intercellular hyphae of both Avr4-producing and non-Avr4-producing strains of $C$. fulvum were stained with Avr4-BDP. The signal of Avr4-BDP was not equally distributed over the intercellular hyphae, and we suggest that this might reflect differences in cell wall composition of nonsynchronously growing infectious hyphae (at this stage of infection, the intercellular hyphae branch actively). Labeling of intercellular hyphae with WGAOG was less effective than with Avr4-BDP. This may reflect differences in the pore sizes of the cell wall matrix of infectious hyphae. A smaller pore size could limit the free diffusion of WGA to a larger extent than that of Avr4 due to the larger size of WGA (WGA forms dimers of $36 \mathrm{kDa}$, whereas Avr4 is a globular protein of only $10 \mathrm{kDa}$ ). As a control experiment, we also examined Avr2-BDP localization on the infectious hyphae. Avr2-BDP does not specifically label runner or infectious hyphae of $C$. fulvum or tomato cells, as expected (results not shown). From these studies, we conclude that chitin is accessible to some degree for Avr4 on infectious C. fulvum hyphae that colonize the tomato apoplast. We believe that this reflects the natural situation where in planta Avr4 is secreted by infectious hyphae and becomes partly integrated in the fungal cell wall. The surplus of nonbound Avr4 protein is released into the

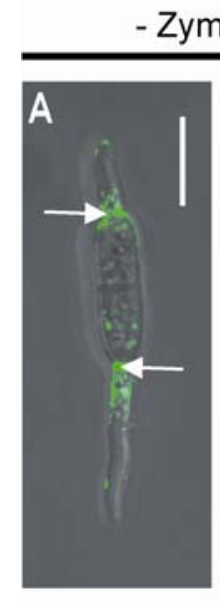

WGA-OG

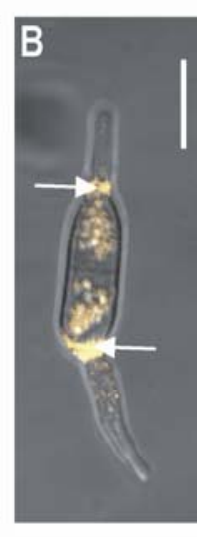

\section{Avr4-BDP}
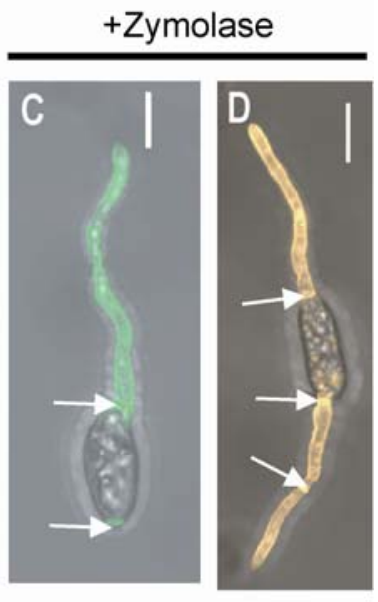

\section{WGA-OG Avr4-BDP}

Fig. 5. Localization of $\mathbf{A}$ and $\mathbf{C}$, dye-conjugated wheat germ agglutinin (WGA) and $\mathbf{B}$ and $\mathbf{D}$, avirulence protein (Avr) 4 on germinating conidia of Cladosporium fulvum in the absence of Zymolase or after pretreatment with Zymolase. A and B, Localization of Avr4-BDP and WGA-Oregon green (OG) at hyphal cell walls in the absence of Zymolase; Avr4-BODIPY-TMRSE (BDP) and WGA-OG do not localize at the hyphal cell wall of in vitrogerminated conidia of C. fulvum except for the site where the germ tube protrudes from the conidium. Avr4-BDP localization also is observed at particular vesicular structures inside the conidium. $\mathbf{C}$ and $\mathbf{D}$, Localization of Avr4BDP and WGA-OG at hyphal cell walls after treatment with Zymolase at 25 $\mathrm{mg} / \mathrm{ml}$. The arrows $(\rightarrow)$ indicate septa; bar $=10 \mu \mathrm{m}$.
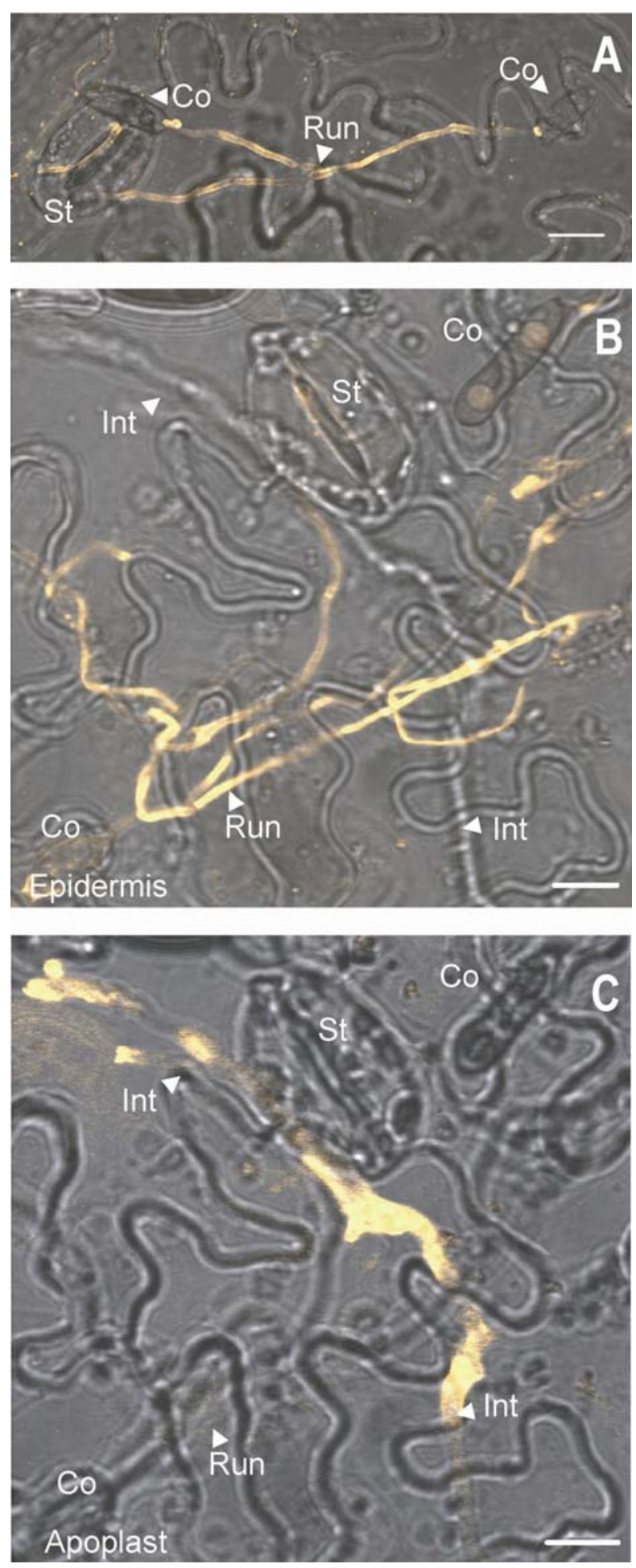

Fig. 6. Chitin is accessible for avirulence protein (Avr)4 at cell walls of infectious hyphae of Cladosporium fulvum inside the apoplast of infected tomato. A, Localization of Avr4-BODIPY-TMR-SE (BDP) $(10 \mu \mathrm{M})$ on an epidermal peeling of a $C$. fulvum-infected tomato leaf (cv. MM-Cf-0) 5 days post inoculation (dpi) with race 5 of $C$. fulvum. Avr4-BDP localizes at the surface of the runner hyphae. B, Avr4-BDP localization on runner hyphae of race 4 of $C$. fulvum infecting tomato (cv. MM-Cf-0) at 9 dpi. Application of $10 \mu \mathrm{M}$ Avr4-BDP by vacuum infiltration of the leaf allowed staining of both runner and intercellular hyphae. After $4 \mathrm{~h}$ of incubation, the epidermis was peeled off and examined. $\mathbf{C}$, Identical epidermal peeling as shown in B; however, confocal plane was localized at the apoplastic side of the epidermal layer showing Avr4-BDP localization at infectious intercellular hyphae present in the apoplast. Co, conidium; Int, intercellular infectious hyphae; Run, runner hyphae on epidermal surface; St, stomatal opening; Bar $=20 \mu \mathrm{m}$. 
apoplast of susceptible MM-Cf0 plants and is recognized by the Cf- 4 protein in MM-Cf-4 plants that mount an HR and, hence, are resistant to strains of $C$. fulvum producing wild-type Avr4 protein.

\section{DISCUSSION}

Protection against plant defense responses is crucial for successful colonization of their hosts by plant pathogens. Therefore, plant pathogens are thought to produce an array of effectors that can interfere with plant defense responses. Here, we give evidence that the $C$. fulvum elicitor Avr4 functions as a cell wall protein that provides protection against tomato chitinases during host penetration and colonization. Several lines of evidence support this conclusion. Avr4 binds specifically to purified chitin (chitin present in cell wall extracts) and in vivo Avr4 binds to chitin present in cell walls of the fungi $C$. fulvum, $T$. viride, and $F$. solani $\mathrm{f}$. sp. phaseoli. The latter two are well established model fungi for assaying antimicrobial activity of plant chitinases and $\beta$-1,3-glucanases (Mauch et al. 1988; SelaBuurlage et al. 1993). Concentrations of Avr4 between 1 and 3 $\mu \mathrm{M}$ rescued growth of both of these fungi in the presence of deleterious concentrations of plant chitinases and $\beta$-1,3-glucanases. Finally, we showed in vivo that Avr4 binds to cell walls of infectious hyphae of $C$. fulvum. Under these conditions, Avr4 normally is secreted by the fungus in concentrations comparable to those that can protect the fungus against plant chitinases, strongly indicating that Avr4 will accumulate on the cell wall during cell wall synthesis when the fungus is colonizing the plant.

Genes encoding plant chitinases and $\beta$-1,3-glucanases have been introduced in many transgenic crop species, including tomato, apple, rice, tobacco, wheat, strawberry, and potato to, increase fungal resistance in these crops (Punja 2001). Avr4 is a clear case study of how a plant-pathogenic fungus has developed a tool to circumvent this type of naturally induced and transgenically introduced resistance in plants. It is important to note that proteins encoding a novel type of chitin-binding motif were identified in the genome of the rice blast fungus Magnaporthe grisea (Dean et al. 2005). The motif is overrepresented in the genome of $M$. grisea because 21 open reading frames (ORFs) contain this particular motif, of which 9 code for putative chitin-binding lectins with functions possibly similar to those of Avr4. Functional analysis of the founding member of this class of putative chitin-binding proteins, $\mathrm{CBP} 1$, showed that it is required for appressorium formation (Kamakura et al. 2002). Therefore, these two different classes of chitin-binding lectins could prove to be diagnostic for additional, as yet unknown chitin-binding lectins in other filamentous fungi.

However, the chitin-binding domain found in Avr4 (CBM14) has not yet been identified in other filamentous fungi. We and others (Dean et al. 2005) were unable to detect CBM14 in ORFs of the fully sequenced genomes of $M$. grisea, Neurospora crassa, Cryptococcus neoformans, Ustilago maydis, Phanerochaete chrysosporium, and Saccharomyces cerevisiae. Also, the analysis of fungal expressed sequence tag databases did not provide homologues of CBM14. However, three single ORFs in the genomes of Aspergillus nidulans, A. oryzae, and A. fumigatus recently were annotated to code for a small secreted protein with a single CBM14 motif (Fig. 7). The primary sequence conservation between the three ORFs (approximately $70 \%$ similarity and $46 \%$ identity at the protein level for the most conserved stretch representing CBM14) suggests that these genes are homologues. All three ORFs contain the canonical six cysteine residues that form three strictly conserved disulfide bonds plus the conserved hydrophobic or aromatic stretches. The residues putatively involved in chitin binding also are conserved between Avr4 (D73 and Y74) (van den Burg et al. 2004) and these three ORFs. This finding highlights that Avr4 is not unique among filamentous ascomycetes.

The latter findings suggest that the proposed intrinsic function of Avr4 might represent one of various adaptive responses occurring in filamentous plant pathogens against hostile host environments. This may be exemplified for the fungi $F$. solani f. sp. phaseoli and Nectria haematococca, which normally are both sensitive to plant $\beta$-1,3-glucanases (PR-2) and chitinases (PR-3), but became tolerant after a short preexposure to low concentrations of these enzymes, which was not due to inactivation of these enzymes by these fungi (Ludwig and Boller 1990; Sela-Buurlage 1996; Sela-Buurlage et al. 1993). This suggests that both fungi respond to enzymatic attack by modifying their cell walls, thereby rendering them tolerant after preexposure to these enzymes. An additional example represents the family of glucanase-inhibitor proteins (GIPs), which are secreted by the oomycete Phytophthora sojae (and several other Phytophthora spp.) and which specifically inhibit plant $\beta$-1,3-glucanases (Bishop et al. 2005; Ham et al. 1997; Rose et al. 2002; York et al. 2004). Cell walls of oomycetes do not contain chitin, but contain mainly $\beta-1,3-$ and $\beta-1,6$-glucans. GIPs accumulate on the surface of hyphal walls of Phytophthora spp. Thus, the function of GIPs for Phytophthora spp. appears to be similar to that of Avr4 for C. fulvum described in this article.

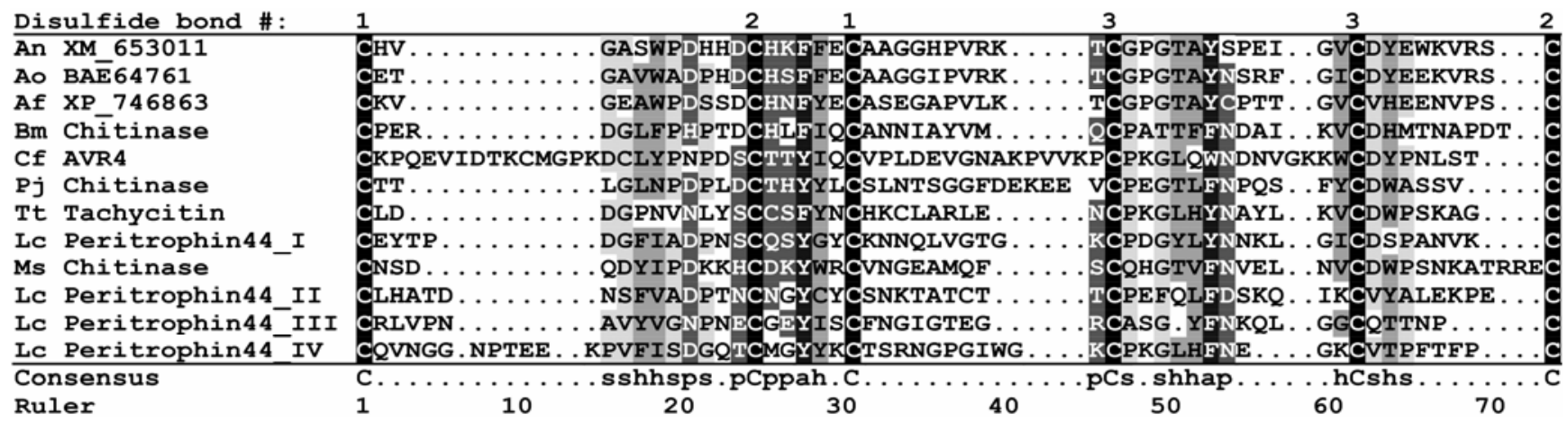

Fig. 7. Alignment of the CBM14 domain found in Aspergillus nidulans (ORF XP_658103), A. oryzae (ORF BAE64761), and A. fumigatus (ORF XP_746863), with several well-characterized CBM14 domains (i.e., avirulence protein [Āvr]4, three times a CBM14 domain found in chitinases from Brugia malayi [P29039], Penaeus japonicus [O15993], and Manduca sexta [P36362]), the antimicrobial protein Tachycitin from Tachypleus tridentatus (P91818), and Peritrophin44 (2211343A) from Lucillia cuprina containing four CBM14 domains. Consensus: a, aromatic; h, hydrophobic; p, polar; s, small residue. NCBI protein accession codes are given between brackets. Alignment was build using ClustalW. The conserved three disulfide bonds are indicated as numbers at the top. 
The environment that $C$. fulvum encounters during colonization of the apoplast becomes increasingly hostile, because chitinases and $\beta-1,3$-glucanases are not only constitutively present, but the corresponding genes also are induced and the encoded proteins accumulate during infection by both virulent and avirulent strains (Joosten and De Wit 1989). Immunogold labeling of these proteins showed that they accumulate close to or on intercellular hyphae of C. fulvum (Wubben et al. 1992) and other fungi that infect tomato (Benhamou et al. 1990). In vitro growth inhibition studies with tomato chitinases and $\beta$-1,3-glucanases already had shown that $C$. fulvum is rather tolerant to these cell-wall-degrading enzymes (Joosten et al. 1995). Avr4 cannot provide protection against chitinases and $\beta-1,3$-glucanases to $C$. fulvum grown in vitro, because the Avr4 gene is not or hardly expressed in vitro (Joosten et al. 1997). Therefore, other factors also must contribute to the tolerance to these enzymes. Zymolase treatments demonstrated that, during in vitro growth, the hyphal cell wall of $C$. fulvum becomes covered by cell wall proteins and glucans that limit chitin accessibility. Zymolase is a commercial preparation of different glucanases and proteases. Possible C. fulvum cell wall proteins are among others glycosyl-phosphatidylinositol (GPI-) anchored proteins (and other glycoproteins) and hydrophobins (Wessels 1997).

Our data show that Avr4 can effectively protect fungi against hydrolysis by basic plant chitinases. This class of plant chitinases not only has the highest hydrolyzing activity on noncrystalline chitin (Brunner et al. 1998), but also has the highest antifungal activity (Sela-Buurlage et al. 1993). This is due to the fact that basic chitinases contain not only an enzymatic domain but also a chitin-binding domain named CBM18 (alternatively referred to as Hevein domain) (Beintema 1994; Passarinho and De Vries 2002). This lectin domain keeps the enzyme in close proximity to the insoluble substrate. Many carbohydratedegrading enzymes contain a nonenzymatic lectin domain in addition to the enzymatic moiety, which has been shown to enhance the hydrolysis of noncrystalline polysaccharides (Boraston et al. 2004). Thus, based on the fact that Avr4 protects growth of $T$. viride and $F$. solani $\mathrm{f}$. sp. phaseoli when exposed to basic chitinases, we conclude that the protective effect of Avr4 at concentrations between 1 and $4 \mu \mathrm{M}$ might be relevant. Moreover, Avr4 concentrations are likely to peak near the growing hyphal tip, which is the site of protein secretion in filamentous fungi (Conesa et al. 2001), and the location where chitin polymers are integrated into the nascent cell wall. In addition, growth inhibition studies with $T$. viride have shown that the hyphal tip is most sensitive to chitinases, causing the tip to swell and burst (Mauch et al. 1988; Schlumbaum et al. 1986). Avr4 concentrations were found to be lower than Avr9 concentrations in tomato apoplastic fluid isolated from a compatible interaction, although both corresponding genes are highly expressed in planta (Joosten et al. 1994, 1997). This observation suggests that Avr4 is retained by chitin in the cell wall of the hyphae of C. fulvum.

The Avr4 affinity-precipitation studies clearly established that Avr4 specifically binds to chitin and fungal cell walls, but not to other polysaccharides or tomato cell walls. Westerink and associates (2002) already have reported a fungal-derived high-affinity binding site (HABS) for Avr4 $\left(K_{\mathrm{d}}=0.05 \mathrm{nM}\right)$. This HABS was heat and protease $\mathrm{K}$ resistant, which implies that chitin could have been the HABS in these experiments. Concurrently, a bioinformatics study revealed a chitin-binding motif (i.e., CBM14) in Avr4, which proved to be functional in binding studies using chito-oligomers of different length (van den Burg et al. 2003, 2004). It also was shown that the affinity of Avr4 for chito-oligomers increases in an allosteric manner when two Avr4 molecules bind to $(\mathrm{GlcNac})_{6}$. It generally is known for CBM modules with affinity for insoluble noncrys- talline polysaccharides (e.g., chitin) that they have enhanced affinity (approximately 10- to 20-fold) for the insoluble noncrystalline polysaccharides compared with soluble polysaccharides (Boraston 2005). This fact, combined with the allosteric interactions, suggests that the $K_{\mathrm{d}}$ of Avr4 for noncrystalline chitin could be in the nanomolar range. Thus, chitin could correspond to the fungus-derived HABS found for Avr4 (Westerink et al. 2002).

Finally, chito-oligomers have been reported to act as general elicitors of the plant defense response, including the accumulation of antimicrobial compounds (Côté and Hahn 1994; Ebel and Cosio 1994). The release of chito-oligomers from the fungal cell wall could be inhibited by the binding of Avr4 to chitin. In addition, not all Avr4 produced is trapped in the cell wall matrix, suggesting that the unbound extracellular Avr4 fraction could trap chito-oligomers that are released from the cell wall matrix. By this mechanism, Avr4 could, in principle, (partially) suppress the general defense response that is triggered by chito-oligomers. However, the $K_{\mathrm{d}}$ of the plant-derived HABS for small chito-oligomers is 20 to $50 \mathrm{nM}$ (Baureithel et al. 1994; Bradley Day et al. 2001), which is two to three magnitudes lower than the $K_{\mathrm{d}}$ of Avr4 for small soluble chito-oligomers (van den Burg et al. 2004). Thus, the plant HABS binds chito-oligomers with a much higher affinity compared with Avr4, suggesting that that it will compete easily for soluble chito-oligomers with the soluble Avr4 fraction. Thus, the main function of Avr4 for $C$. fulvum during tomato infection appears to be the protection of chitin in the growing hyphal tips against plant chitinases. In addition, Avr4 could inhibit the release of soluble chitooligomers. However, in Cf-4 plants, freely available Avr4 will trigger $\mathrm{Cf}-4$-mediated $\mathrm{HR}$ and resistance against the fungus and, in these plants, infection by Avr4-producing C. fulvum strains is unsuccessful. Interestingly, strains of $C$. fulvum that are no longer recognized by Cf-4 produce Avr 4 isoforms that are degraded easily by proteases present in the tomato apoplast (Joosten et al. 1997; van den Burg et al. 2003). However, for some of these Avr4 isoforms, it was shown that they still are able to bind chitin and that binding to chitin (partially) rescued these Avr4 isoforms from degradation by proteases present in tomato apoplastic fluid (van den Burg et al. 2003). This might explain why, on MM-Cf4 plants, strains of $C$. fulvum producing chitin-binding isoforms of Avr4 are virulent and seem to be rather fit. Studies are underway to knock out the Avr4 gene in C. fulvum and compare the fitness of such a mutant with that of the wildtype parent on MM-Cf-0 tomato plants.

\section{MATERIALS AND METHODS}

\section{Reagents.}

Mature forms of Avr2 and Avr4 were produced in the methylotrophic yeast Pichia pastoris and purified from culture filtrate (Rooney et al. 2005; van den Burg et al. 2001). Tobacco basic chitinase (ChiI) (EC 3.2.1.14) and basic $\beta$-1,3-glucanase (GluI) (EC 3.2.1.39) were overexpressed in Escherichia coli and purified according to Jongedijk and associates (1995). Ecp1 and Ecp4 protein were purified from apoplastic fluid obtained from a compatible interaction between C. fulvum and tomato as described by Laugé and associates (2000).

\section{Purification of cell walls.}

Crude cell wall material was isolated from tomato plants and two different fungi. Plants were grown in contained environments in the greenhouse to prevent fungal infections. Strains of the fungi $C$. fulvum (race 4 and race 5) and $T$. viride were grown for 3 days in liquid shake cultures containing sup- 
plemented B5 medium (Van den Ackerveken et al. 1993). Under these conditions, expression of the Avr4 gene is suppressed (Joosten et al. 1997). Fungal mycelium and leaves of 6-weekold tomato plants (cv. Moneymaker $\mathrm{Cf0}$ and near-isogenic line MM-Cf4) were homogenized in a Waring blender in the presence of 7 parts (vol/wt) of a solution consisting of $80 \%$ (wt/wt) buffer-saturated phenol (Life Technologies, Gaithersburg, MD, U.S.A.)/acetic acid/water (PAW) in a ratio of 2.5:1:1 ( $\mathrm{vol} / \mathrm{vol} / \mathrm{vol}$ ). After stirring for $18 \mathrm{~h}$ at room temperature, the homogenate was filtered over a glass filter and the insoluble fraction was collected, resuspended in 5 parts of PAW, and incubated for another $24 \mathrm{~h}$. This procedure was repeated two times. By this time most protein had been removed, which was verified by adding $50 \mu \mathrm{l}$ of $10 \%$ ammonium formate and $5 \mathrm{ml}$ of acetone to $1 \mathrm{ml}$ of filtrate. Absence of a precipitate indicated absence of residual proteins. This glycan-enriched cell wall fraction subsequently was rinsed extensively with $70 \%$ ethanol and lyophilized before storage.

\section{Polysaccharide affinity precipitation assay.}

The affinity of Avr4, WGA, Ecp1, and Ecp4 for various polysaccharides was determined by incubating each of these proteins (at a concentration of $5 \mu \mathrm{g} / \mathrm{ml}$ ) with the following insoluble polysaccharides $(5 \mathrm{mg}$ ): chitin beads (New England Biolabs, Beverly, MA, U.S.A.), crab shell chitin, chitosan, xylan, cellulose, curdlan (1,3- $\beta$-D glucan from bacteria), and lichenan (1,3- to 1,4- $\beta$-D glucan from lichens) (all from Sigma, St. Louis) as described previously (Tjoelker et al. 2000). The incubations were performed in $800 \mu \mathrm{l}$ of buffer containing 50 $\mathrm{mM}$ Tris/ $\mathrm{HCl}, \mathrm{pH} 8$, and $150 \mathrm{mM} \mathrm{NaCl}$. After $2 \mathrm{~h}$ of gentle rocking at ambient temperature, the insoluble fraction was pelleted by centrifugation $(3 \mathrm{~min}, 13,000 \times g)$ and the supernatant was collected. The insoluble fraction was washed three times with incubation buffer and subsequently boiled in $200 \mu \mathrm{l}$ of $1 \%$ SDS solution. Presence of proteins (Avr4, Ecp1, Ecp2, or WGA) in both supernatant and pellet was examined by Tricine SDS-polyacrylamide gel electrophoresis followed by standard silver or Coomassie staining. The precipitation of Avr4 with plant and fungal cell wall extracts $(5 \mathrm{mg})$ was performed in a similar manner.

\section{Chitinase activity assay.}

Chitin azure suspensions (100 $\mu \mathrm{l}$ of start volume, $1 \mathrm{mg} / \mathrm{ml}$; Sigma) were incubated with a dilution series of Avr4, Ecp1, or Avr4 that had been preincubated with a threefold molar excess of (GlcNAc) $)_{6}(10 \mu \mathrm{l}$ was added with a final concentration of $3.5 \mu \mathrm{M})$. After $3 \mathrm{~h}$ of incubation at $37^{\circ} \mathrm{C}$ on a shaker, $50 \mu \mathrm{g}$ of ChiI (dissolved in $190 \mu \mathrm{l}$ of $100 \mathrm{mM}$ sodium acetate buffer, $\mathrm{pH}$ 5.2) was added and the incubation was prolonged for $10 \mathrm{~h}$. Chitinase activity was determined by measuring the absorption at $\mathrm{A}_{550}$ of the supernatant after removal of the residual insoluble chitin azure by centrifugation.

\section{Fungal growth assay \\ in the presence of chitinases and $\beta-1,3$-glucanases.}

Fungal growth assays were performed essentially according to Sela-Buurlage and associates (1993). Conidia (10 ${ }^{4}$ conidia/ $\mathrm{ml}$ ) of $T$. viride and $F$. solani $\mathrm{f}$. sp. phaseoli were incubated overnight in liquid media (Czapex-Dox or potato dextrose broth, respectively). The conidial suspensions were dispensed into 96-wells microtiter plates in aliquots of $50 \mu \mathrm{l}$, together with $10 \mu \mathrm{l}$ of a dilution series of Avr4. After incubation for $2 \mathrm{~h}$, the enzyme solution was added $(40 \mu \mathrm{l})$. ChiI and GluI both were applied at a final concentration of $0.3 \mu \mathrm{M}$. T. viride was incubated only with ChiI, whereas $F$. solani f. sp. phaseoli was incubated with a mixture of both enzymes. Fungal growth was scored after incubation for $24 \mathrm{~h}$ at $22^{\circ} \mathrm{C}$.

\section{Localization of Avr4 and WGA labeled with fluorescent dyes.}

Proteins were labeled with the amine-reactive fluorescent dye BDP (excitation wavelength [Ex] $543 \mathrm{~nm}$; Invitrogen, Carlsbad, CA, U.S.A.) according to the manufacturer's recommendations. The reaction resulted in the coupling of approximately 0.3 to $0.5 \mathrm{BDP}$ per protein molecule. Nonreacted free dye was separated from the dye-labeled protein by size-exclusion chromatography (P6-DG; Bio Rad, Hercules, CA, U.S.A.). Avr4-BDP was used at concentrations of 0.5 to $4 \mu \mathrm{M}$ and WGA- OG (Ex $488 \mathrm{~nm}$, Invitrogen) was applied at concentrations of 5 to $20 \mu \mathrm{M}$ without remarkable differences in staining patterns for the different concentrations. Conidia were pregerminated overnight in liquid culture. Enzymatic treatments of germinated conidia lasted for up to $5 \mathrm{~h}$. Zymolase (Zymo Research, Orange, CA, U.S.A.) was used at a concentration of $25 \mu \mathrm{g} / \mathrm{ml}$ and Pronase was used at a concentration of $50 \mu \mathrm{g} / \mathrm{ml}$. The proteolytic activity in Zymolase was inhibited using $1 \times$ complete protease inhibitors (Roche, Branchburg, NJ, U.S.A.). After staining, the germinated conidia were washed three times in standard phosphate-buffered saline (PBS) and fluorescence was detected with a confocal laser-scanning microscope (Carl Zeiss, Oberkochen, Germany). For in planta localization of fluorescently labeled Avr4 and WGA, 6-week-old tomato plants were inoculated with $C$. fulvum (race 4 and race 5). Staining of leaf material was achieved by vacuum infiltration of the dye into the apoplast of the infected tomato leaves (De Wit and Spikman 1982) or by incubation of epidermal peelings (Joosten et al. 1997 ) in PBS containing dye-labeled protein. Epidermal peelings were washed three times with PBS prior to the detection of the dye by CLSM. All fluorescent stainings were performed at $20^{\circ} \mathrm{C}$ in the dark.

\section{ACKNOWLEDGMENTS}

H. A. van den Burg was supported by a combined research grant from the Netherlands Foundation of Chemical Research (CW) and the Netherlands Foundation of Earth and Life Sciences (ALW), both part of the Netherlands Organisation for Scientific Research (NWO).

\section{LITERATURE CITED}

Bains, G., Lee, R. T., Lee, Y. C., and Freire, E. 1992. Microcalorimetric study of wheat germ agglutinin binding to $\mathrm{N}$-acetylglucosamine and its oligomers. Biochemistry 31:12624-12628.

Baureithel, K., Felix, G., and Boller, T. 1994. Specific, high affinity binding of chitin fragments to tomato cells and membranes. Competitive inhibition of binding by derivatives of chitooligosaccharides and a Nod factor of Rhizobium. J. Biol. Chem. 269:17931-17938.

Beintema, J. J. 1994. Structural features of plant chitinases and chitinbinding proteins. FEBS (Fed. Eur. Biochem. Soc.) Lett. 350:159-163.

Benhamou, N., Joosten, M. H. A. J., and De Wit, P. J. G. M. 1990. Subcellular localization of chitinase and of its potential substrate in tomato root tissues infected by Fusarium oxysporum f. sp. radicici-lycopersici. Plant Physiol. 92:1108-1120.

Bishop, J. G., Ripoll, D. R., Bashir, S., Damasceno, C. M., Seeds, J. D. and Rose, J. K. 2005. Selection on Glycine beta-1,3-endoglucanase genes differentially inhibited by a Phytophthora glucanase inhibitor protein. Genetics 169:1009-1019.

Boraston, A. B. 2005. The interaction of carbohydrate-binding modules with insoluble non-crystalline cellulose is enthalpically driven. Biochem. J. 385:479-484.

Boraston, A. B., Bolam, D. N., Gilbert, H. J., and Davies, G. J. 2004. Carbohydrate-binding modules: Fine-tuning polysaccharide recognition. Biochem. J. 382:769-781.

Bradley Day, R., Okada, M., Ito, Y., Tsukada, K., Zaghouani, H., Shibuya, N., and Stacey, G. 2001. Binding site for chitin oligosaccharides in the soybean plasma membrane. Plant Physiol. 126:1162-1173.

Brunner, F., Stintzi, A., Fritig, B., and Legrand, M. 1998. Substrate specificities of tobacco chitinases. Plant J. 14:225-234.

Conesa, A., Punt, P. J., Van Luijk, N., and Van den Hondel, C. A. M. J. J. 
2001. The secretion pathway in filamentous fungi: A biotechnical view. Fungal Genet. Biol. 33:155-171.

Côté, F., and Hahn, M. G. 1994. Oligosaccharins: Structures and signal transduction. Plant Mol. Biol. 26:1379-1411.

Darvill, A. G., and Albersheim, P. 1984. Phytoalexins and their elicitors- a defense against microbial infection in plants. Annu. Rev. Plant Physiol. 35:243-275

Datta, S. K., and Muthukrishnan, S. 1999.Pathogenesis-Related Proteins in Plants. CRC Press, Washington, DC.

Daugrois, J. H., Lafitte, C., Barthe, J. P., and Touze, A. 1990. Induction of beta-1,3-glucanase and chitinase activity in compatible and incompatible interactions between Colletotrichum lindemuthianum and bean cultivars. J. Phytopathol. 130:225-234.

Dean, R. A., Talbot, N. J., Ebbole, D. J., Farman, M. L., Mitchell, T. K., Orbach, M. J., Thon, M., Kulkarni, R., Xu, J. R., Pan, H., Read, N. D., Lee, Y. H., Carbone, I., Brown, D., Oh, Y. Y., Donofrio, N., Jeong, J. S., Soanes, D. M., Djonovic, S., Kolomiets, E., Rehmeyer, C., Li, W., Harding, M., Kim, S., Lebrun, M. H., Bohnert, H., Coughlan, S., Butler, J., Calvo, S., Ma, L. J., Nicol, R., Purcell, S., Nusbaum, C., Galagan, J. E., and Birren, B. W. 2005. The genome sequence of the rice blast fungus Magnaporthe grisea. Nature 434:980-986.

De Groot, P. W. J., Ram, A. F., and Klis, F. M. 2005. Features and functions of covalently linked proteins in fungal cell walls. Fungal Genet. Biol. 42:657-675.

De Kock, M. J. D., Brandwagt, B. F., Bonnema, G., De Wit, P. J. G. M., and Lindhout, P. 2004a The tomato Orion locus comprises a unique class of Hcr9 genes. Mol. Breed. 15:409-422.

De Kock, M. J. D., Iskandar, H. M., Brandwagt, B. F., Lauge, R., De Wit, P. J. G. M., and Lindhout, P. 2004b. Recognition of Cladosporium fulvum Ecp2 elicitor by non-host Nicotiana spp. is mediated by a single dominant gene that is not homologous to known $C f$-genes. Mol. Plant Pathol. 5:397-408.

De Wit, P. J. G. M. 1977. A light and scanning-electron microscopic study of the infection of tomato plants by virulent and avirulent races of Cladosporium fulvum. Neth. J. Plant Pathol. 83:109-122.

De Wit, P. J. G. M., and Spikman G. 1982. Evidence for the occurrence of race and cultivar-specific elicitors of necrosis in intercellular fluids of compatible interactions of Cladosporium fulvum and tomato. Physiol. Plant Pathol. 21: 1-11.

De Wit, P. J. G. M., Brandwagt, B. F., van den Burg, H. A., Cai, X., Van der Hoorn, R. A. L., De Jong, C. F., Van Klooster, J., De Kock, M. J. D., Kruijt, M., Lindhout, W. H., Luderer, R., Takken, F. L., Westerink, N., Vervoort, J., and Joosten, M. H. A. J. 2002. The molecular basis of coevolution between Cladosporium fulvum and tomato. Antonie Leeuwenhoek 81:409-412.

Ebel, J., and Cosio, E. G. 1994. Elicitors of plant defense responses. Int. Rev. Cytol. 148:1-36.

Grison, R., Grezes-Besset, B., Schneider, M., Lucante, N., Olsen, L., Leguay, J. J., and Toppan, A. 1996. Field tolerance to fungal pathogens of Brassica napus constitutively expressing a chimeric chitinase gene. Nat. Biotechnol. 14:643-646.

Ham, K. S., Wu, S. C., Darvill, A. G., and Albersheim, P. 1997. Fungal pathogens secrete an inhibitor protein that distinguishes isoforms of plant pathogenesis-related endo-beta-1,3-glucanases. Plant J. 11:169-179.

Hu, G., and Rijkenberg, F. H. 1998. Subcellular localization of beta-1,3glucanase in Puccinia recondita f. sp. tritici-infected wheat leaves. Planta 204:324-334.

Jongedijk, E., Tigelaar, H., Van Roekel, J. S. C., Bres-Vloemans, S. A., Dekker, I., Van den Elzen, P. J. M., Cornelissen, B. J. C., Melchers L. S. 1995. Synergistic activity of chitinases and beta-1,3-glucanases enhances fungal resistance in transgenic tomato plants. Euphytica 85:173-180.

Joosten, M. H. A. J., Cozijnsen, T. J., and De Wit, P. J. G. M. 1994. Host resistance to a fungal tomato pathogen lost by a single base-pair change in an avirulence gene. Nature 367:384-386.

Joosten, M. H. A. J., and De Wit, P. J. G. M. 1989. Identification of several pathogenesis-related proteins in tomato leaves inoculated with Cladosporium fulvum (syn. Fulvia fulva) as 1,3-beta-glucanases and chitinases. Plant Physiol. 89:945-951.

Joosten, M. H. A. J., and De Wit, P. J. G. M. 1999. The tomato-Cladosporium fulvum interaction: A versatile experimental system to study plantpathogen interactions. Annu. Rev. Phytopathol. 37:335-367.

Joosten, M. H. A. J., Verbakel, H. M., Nettekoven, M. E., Van Leeuwen, J., Vossen, R. T. M., and De Wit, P. J. G. M. 1995. The phytopathogenic fungus Cladosporium fulvum is not sensitive to the chitinase and beta1,3-glucanase defense proteins of its host, tomato. Physiol. Mol. Plant Pathol. 46:45-59.

Joosten, M. H. A. J., Vogelsang, R., Cozijnsen, T. J., Verberne, M. C., and De Wit, P. J. G. M. 1997. The biotrophic fungus Cladosporium fulvum circumvents $C f$-4-mediated resistance by producing unstable Avr4 elicitors. Plant Cell 9:367-379.
Jorda, L., Coego, A., Conejero, V., and Vera, P. 1999. A genomic cluster containing four differentially regulated subtilisin-like processing protease genes in tomato plants. J. Biol. Chem. 274:2360-2365.

Jorda, L., and Vera, P. 2000. Local and systemic induction of two defenserelated subtilisin-like protease promoters in transgenic Arabidopsis plants. Luciferin induction of PR gene expression. Plant Physiol. 124:1049-1058.

Kamakura, T., Yamaguchi, S., Saitoh, K.-I., Teraoka, T., and Yamaguchi, I. 2002. A novel gene, $C B P 1$, encoding a putative extracellular chitinbinding proteins, may play an important role in the hydrophobic surface sensing of Magnaporthe grisea during appressorium differentiation. Mol. Plant-Microbe Interact. 15:437-444.

Kang, Z., and Buchenauer, H. 2002. Immunocytochemical localization of beta-1,3-glucanase and chitinase in Fusarium culmorum -infected wheat spikes. Physiol. Mol. Plant Pathol. 60:141-153.

Kawabata, S., Nagayama, R., Hirata, M., Shigenaga, T., Agarwala, K. L. Saito, T., Cho, J., Nakajima, H., Takagi, T., and Iwanaga, S. 1996. Tachycitin, a small granular component in horseshoe crab hemocytes, is an antimicrobial protein with chitin-binding activity. J. Biochem. 120:1253-1260.

Krüger, J., Thomas, C. M., Golstein, C., Dixon, M. S., Smoker, M., Tang, S., Mulder, L., and Jones, J. D. G. 2002. A tomato cysteine protease required for $\mathrm{Cf}-2-$ dependent disease resistance and suppression of autonecrosis. Science 296:744-747.

Laugé, R., Goodwin, P. H., De Wit, P. J. G. M., and Joosten, M. H. A. J. 2000. Specific HR-associated recognition of secreted proteins from Cladosporium fulvum occurs in both host and non-host plants. Plant J. 23:735-745.

Laugé, R., Joosten, M. H. A. J., Van den Ackerveken, G. F. J. M., Van den Broek, H. W. J., and De Wit, P. J. G. M. 1997. The in planta-produced extracellular proteins ECP1 and ECP2 of Cladosporium fulvum are virulence factors. Mol. Plant-Microbe Interact. 10:725-734.

Luderer, R., Takken, F. L., De Wit, P. J. G. M., and Joosten, M. H. A. J. 2002. Cladosporium fulvum overcomes Cf-2-mediated resistance by producing truncated Avr2 elicitor proteins. Mol. Microbiol. 45:875-884.

Ludwig, A., and Boller, T. 1990. A method for the study of fungal growth inhibition by plant proteins. FEMS (Fed. Eur. Microbiol. Soc.) Microbiol. Lett. 69:61-66.

Marmeisse, R., Van den Ackerveken, G. F. J. M., Goosen, T., De Wit, P. J. G. M., and Van den Broek, H. W. J. 1994. The in-planta induced ecp2 gene of the tomato pathogen Cladosporium fulvum is not essential for pathogenicity. Curr. Genet. 26:245-250.

Mauch, F., Mauch-Mani, B., and Boller, T. 1988. Antifungal hydrolases in pea tissue. Part II. Inhibition of fungal growth by combinations of chitinase and beta-1,3-glucanase. Plant Physiol. 88:936-942.

Passarinho, P., and De Vries, S. C. 2002. Arabidopsis chitinases: A genomic survey. In: The Arabidopsis Book. C. R. Sommerville and E. M. Meyerowitz, eds. American Society of Plant Biologists, Rockville, MD, U.S.A. DOI: 10.1199/tab.0023 25. Published online.

Punja, Z. K. 2001. Genetic engineering of plants to enhance resistance to fungal pathogens - a review of progress and future prospects. Can. J. Plant Pathol. 23:216-235.

Rivas, S., and Thomas, C. M. 2005. Molecular interactions between tomato and the leaf mold pathogen Cladosporium fulvum. Annu. Rev. Phytopathol. 43:395-436.

Rooney, H. C., Van 't Klooster, J. W., Van der Hoorn, R. A., Joosten, M. H. A. J., Jones, J. D. G., and De Wit, P. J. G. M. 2005. Cladosporium Avr2 inhibits tomato Rcr3 protease required for Cf-2-dependent disease resistance. Science 308:1783-1786.

Rose, J. K. C., Ham, K. S., Darvill, A. G., and Albersheim, P. 2002. Molecular cloning and characterization of Glucanase Inhibitor proteins: Coevolution of a counterdefense mechanism by plant pathogens. Plant Cell 14:1329-1345.

Schlumbaum, A., Mauch, F., Vogeli, U., and Boller, T. 1986. Plant chitinases are potent inhibitors of fungal growth. Nature 324:365-367.

Sela-Buurlage, M. B. 1996. In vitro sensitivity and tolerance of Fusarium solani towards chitinases and beta-1,3-glucanases. Ph.D. thesis, Wageningen University, The Netherlands.

Sela-Buurlage, M. B., Ponstein, A. S., Bres-Vloemans, S. A., Melchers, L. S., Van den Elzen, P. J. M., and Cornelissen, B. J. C. 1993. Only specific tobacco (Nicotiana tabacum) chitinases and beta-1,3-glucanases exhibit antifungal activity. Plant Physiol. 101:857-863.

Shen, Z., and Jacobs-Lorena, M. 1999. Evolution of chitin-binding proteins in invertebrates. J. Mol. Evol. 48:341-347.

Stintzi, A., Heitz, T., Prasad, V., Wiedemann-Merdinoglu, S., Kauffmann, S., Geoffroy, P., Legrand, M., and Fritig, B. 1993. Plant "pathogenesisrelated" proteins and their role in defense against pathogens. Biochimie 75:687-706.

Sudha, G., and Ravishankar, G. A. 2002. Involvement and interaction of various signaling compounds on the plant metabolic events during de- 
fense response, resistance to stress factors, formation of secondary metabolites and their molecular aspects. Plant Cell Tiss. Org. 71: 181-212.

Suetake, T., Tsuda, S., Kawabata, S., Miura, K., Iwanaga, S., Hikichi, K. Nitta, K., and Kawano, K. 2000. Chitin-binding proteins in invertebrates and plants comprise a common chitin-binding structural motif. J. Biol. Chem. 275:17929-17932.

Thomas, C. M., Jones, D. J., Parniske, M., Harrison, K., Balint-Kurti, P. J., Hatzixanthis, K., and Jones, J. D. G. 1997. Characterization of the tomato $C f-4$ gene for resistance to Cladosporium fulvum identifies sequences that determine recognitional specificity in $C f-4$ and $C f-9$. Plant Cell 9:2209-2224.

Thomma, B. P. H. J., Van Esse, H. P., Crous, P. W., and De Wit, P. J. G. M. 2005. Cladosporium fulvum (syns Passalora fulva), a highly specialized plant pathogen as a model for functional studies on plant pathogenic Mycosphaerellaceae. Mol. Plant Pathol. 6:379-393.

Tian, M., Benedetti, B., and Kamoun, S. 2005. A Second Kazal-like protease inhibitor from Phytophthora infestans inhibits and interacts with the apoplastic pathogenesis-related protease P69B of tomato. Plant Physiol. 138:1785-1793.

Tian, M., Huitema, E., Da Cunha, L., Torto-Alalibo, T., and Kamoun, S. 2004. A Kazal-like extracellular serine protease inhibitor from Phytophthora infestans targets the tomato pathogenesis-related protease P69B. J. Biol. Chem. 279:26370-26377.

Tian, M., and Kamoun, S. 2005. A two disulfide bridge Kazal domain from Phytophthora exhibits stable inhibitory activity against serine proteases of the subtilisin family. BMC Biochem. 6:15.

Tjoelker, L. W., Gosting, L., Frey, S., Hunter, C. L., Trong, H. L., Steiner, B., Brammer, H., and Gray, P. W. 2000. Structural and functional definition of the human chitinase chitin-binding domain. J. Biol. Chem. 275:514-520.

Tudzynski, P., and Sharon, A. 2003. Fungal pathogenicity genes. Pages $187-$ 212 in: Applied Mycology and Biotechnology, Vol. 3: Fungal Genomics. D. K. Arora and G. G. Khachatourians, eds. Elsevier, Amsterdam.

Van den Ackerveken, G. F. J. M., Van Kan, J. A. L., Joosten, M. H. A. J., Muisers, J. M., Verbakel, H. M., and De Wit, P. J. G. M. 1993. Characterization of two putative pathogenicity genes of the fungal tomato pathogen Cladosporium fulvum. Mol. Plant-Microbe Interact. 6:210215.

Van den Ackerveken, G. F. J. M., Vossen, P., and De Wit, P. J. G. M. 1993. The Avr9 race-specific elicitor of Cladosporium fulvum is processed by endogenous and plant proteases. Plant Physiol. 103:91-96.

van den Burg, H. A., De Wit, P. J. G. M., and Vervoort, J. 2001. Efficient $\mathrm{C}-13 / \mathrm{N}-15$ double labeling of the avirulence protein Avr4 in a methanol-utilizing strain (Mut(+)) of Pichia pastoris. J. Biomol. NMR 20:251-261.

van den Burg, H. A., Spronk, C. A., Boeren, S., Kennedy, M. A., Vissers, J. P., Vuister, G. W., De Wit, P. J.G.M., and Vervoort, J. 2004. Binding of the Avr4 elicitor of Cladosporium fulvum to chitotriose units is facilitated by positive allosteric protein-protein interactions: The chitin-binding site of Avr4 represents a novel binding site on the folding scaffold shared between the invertebrate and the plant chitin-binding domain. J. Biol. Chem. 279:16786-16796.

van den Burg, H. A., Westerink, N., Francoijs, K. J., Roth, R., Woestenenk, E., Boeren, S., De Wit, P. J. G. M., Joosten, M. H. A. J., and Vervoort, J.
2003. Natural disulfide bond-disrupted mutants of Avr4 of the tomato pathogen Cladosporium fulvum are sensitive to proteolysis, circumvent Cf-4-mediated resistance, but retain their chitin-binding ability. J. Biol. Chem. 278:27340-27346.

Van den Hooven, H. W., van den Burg, H. A., Vossen, P., Boeren, S., De Wit, P. J. G. M., and Vervoort, J. 2001. Disulfide bond structure of the Avr9 elicitor of the fungal tomato pathogen Cladosporium fulvum: Evidence for a cystine knot. Biochemistry 40:3458-3466.

Van Esse, H. P., Thomma, B. P. H. J., Van 't Klooster, J. W., and De Wit, P. J. G. M. 2006. Affinity-tags are removed from Cladosporium fulvum effector proteins expressed in the tomato leaf apoplast. J. Exp. Bot. 57:599-608.

Van Kan, J. A. L., and Van den Ackerveken, G. F. J. M., De Wit P. J. G. M. 1991. Cloning and characterization of complementary DNA of avirulence gene avr 9 of the fungal pathogen Cladosporium fulvum, causal agent of tomato leaf mold. Mol. Plant-Microbe Interact. 4:52-59.

Vervoort, J., Van den Hooven, H. W., Berg, A., Vossen, P., Vogelsang, R., Joosten, M. H. A. J., and De Wit, P. J. G. M. 1997. The race-specific elicitor Avr9 of the tomato pathogen Cladosporium fulvum: A cystine knot protein. FEBS (Fed. Eur. Biochem. Soc.) Lett. 404:153-158.

Wessels, J. G. H. 1997. Hydrophobins: Proteins that change the nature of the fungal surface. Adv. Microbiol. Physiol. 38:1-45.

Wessels, J. G. H., and Sietsma, J. H. 1981. Fungal cell walls: A survey. Pages 352-394 in: Plant Carbohydrates II, Extracellular Carbohydrates, Vol. 13B. W. Tanner and F. A. Loewus, eds. Springer-Verlag, Berlin.

Westerink, N., Brandwagt, B. F., De Wit, P. J. G. M., and Joosten, M. H. A. J. 2004. Cladosporium fulvum circumvents the second functional resistance gene homologue at the Cf-4 locus (Hcr9-4E) by secretion of a stable avr4E isoform. Mol. Microbiol. 54:533-545.

Westerink, N., Roth, R., van den Burg, H. A., De Wit, P. J. G. M., and Joosten, M. H. A. J. 2002. The Avr4 elicitor protein of Cladosporium fulvum binds to fungal components with high affinity. Mol. PlantMicrobe Interact. 15:1219-1227.

Wubben, J. P. 1994. Subcellular localization of fungal and plant proteins in the Cladosporium fulvum-tomato interaction. Ph.D. thesis, Wageningen University, The Netherlands.

Wubben, J. P., Eijkelboom, C. A., and De Wit, P. J. G. M. 1993. Accumulation of pathogenesis-related proteins in the epidermis of tomato leaves infected by Cladosporium fulvum. Neth. J. Plant Pathol. 99:231-239.

Wubben, J. P., Joosten, M. H. A. J., Van Kan, J. A. L., and De Wit, P. J. G. M. 1992. Subcellular localization of plant chitinases and 1,3-beta-glucanases in Cladosporium fulvum infected tomato leaves. Physiol. Mol. Plant Pathol. 41:23-32.

York, W. S., Qin, Q., and Rose, J. K. 2004. Proteinaceous inhibitors of endo-beta-glucanases. Biochim. Biophys. Acta 1696:223-233.

Zhu, Q., Maher, E. A., Masoud, S., Dixon, R. A., and Lamb, C. J. 1994. Enhanced protection against fungal attack by constitutive co-expression of chitinase and glucanase genes in transgenic tobacco. Biotechnology 12:807-812.

\section{AUTHOR-RECOMMENDED INTERNET RESOURCE}

CAZY database, carbohydrate classification system: www.cazy.org/CAZY 